\title{
Pemetaan Batas Lahan Pondok Pesantren Entrepreneur Muhammadiyah Gondanglegi Kabupaten Malang
}

\section{(Mapping of Land Boundaries of the Entrepreneur Muhammadiyah Boarding School Gondanglegi Malang)}

\author{
Azhar Adi Darmawan ${ }^{1 *}$, Amalia Nur Adibah ${ }^{2}$, Khoirul Abadi $^{3}$, Chairil Saleh $^{4}$, Suwignyo ${ }^{5}$ \\ 1,2,3,4,5 Program Studi Sipil, Fakultas Teknik, Universitas Muhammadiyah Malang
}

\begin{abstract}
ARTICLE INFO
ABSTRAK

\section{Article history}

Received : 24 April 2021

Revised : 30 Mei 2021

Accepted : 08 Juni 2021

DOI :

https://doi.org/10.33366/jast. v5i1.2384

Keywords : land boundary; land mapping; topographic mockups

*e-mail corresponding author : azharaadidfts@umm.ac.id

Sistem pondok pesantren yang modern adalah pencampuran antara kurikulum pendidikan nasional dengan milik pesantren, sehingga walaupun bentuknya adalah sebuah pondok pesantren, santri juga memperoleh ilmu dan standar kelulusan seperti pelajar sekolah pada sekolah umum. Pondok Pesantren Entrepreneur Muhammadiyah (PPEM) adalah salah satu unit amal usaha di bawah pengelolaan Pimpinan Cabang Muhammadiyah (PCM) Gondanglegi, Kabupaten Malang. Lahan yang digunakan oleh pondok merupakan lahan wakaf bersertifikat. Seiring dengan pembangunan perumahan di sisi lahan pondok, batas lahan menjadi satu masalah baru, antara pengurus pondok, dengan pihak pengembang perumahan. Terdapat selisih patok dan batas lahan, yang diklaim oleh pengembang perumahan di sebelah pondok. Target dan luaran dari program pengabdian ini yaitu pengurus PPEM dapat menginventarisir lahan melalui pemetaan fisik. Produk kegiatan pengabdian masyarakat ini berupa hasil pemetaan lahan yang teraplikasikan langsung dalam bentuk maket topografi lahan pondok yang telah sesuai dengan hasil pemetaan dan memperkuat sertifikat pondok.
\end{abstract}

\section{PENERBIT}

\section{UNITRI PRESS}

Jl. Telagawarna, TlogomasMalang, 65144, Telp/Fax: 0341565500

\section{(c) (†) (2)}

This is an open access article under the Creative Commons Attribution$\begin{array}{lll}\text { ShareAlike } & 4.0 & \text { International }\end{array}$ License. Any further distribution of this work must maintain attribution to the author(s) and the title of the work, journal citation and DOI. CC-BY-SA

Cara Mengutip : Darmawan, A. A., Adibah, A. N., Abadi, K., Saleh, C., Suwignyo, S. (2021). Pemetaan Batas Lahan Pondok Pesantren Entrepreneur Muhammadiyah Gondanglegi Kabupaten Malang. JAST: Jurnal Aplikasi Sains dan Teknologi, 5(1), 60-68. doi:https://doi.org/10.33366/jast.v5i1.2384 


\section{PENDAHULUAN}

Gondanglegi merupakan salah satu kecamatan yang terletak pada wilayah administratif Kabupaten Malang. Kecamatan Gondanglegi memiliki 14 desa, 31 dusun, 59 RW, dan 385 RT. Salah satu desa yang ada di Kecamatan Gondanglegi terdapat suatu lokasi dimana terdapat kegiatan belajar mengajar berupa sarana pendidikan non profit yang bernama Pondok Pesantren Entrepreneur Muhammadiyah (PPEM). Sebagai pusat pendidikan khususnya pendidikan agama, Pondok Pesantren secara berkelanjutan melakukan pengembangan fasilitas pendukung guna menambah kenyamanan dalam proses belajar dan mengajar. Pendidikan sistem pondok pesantren yang mengharuskan santriwan atau santriwati untuk tinggal dikawasan pondok, merupakan satu dasar bahwa kawasan pondok harus dapat memenuhi semaksimal mungkin kebutuhan santriwan ataupun santriwati dari kebutuhan pokok harian, hingga kebutuhan dalam belajar ilmu agama. Serta perlunya menjaga sanitasi lingkungan agar lingkungan belajar tetap kondusif dan nyaman [1].

Dalam perkembangannya, pondok pesantren tidak hanya memberikan pembelajaran yang bersifat agamis bagi santriwan ataupun santriwati, namun juga pendidikan formal. Sistem pondok pesantren yang modern adalah pencampuran antara kurikulum pendidikan nasional dengan milik pesantren, sehingga walaupun bentuknya adalah sebuah pondok pesantren, selain pendidikan kepondokan atau asrama, santri juga memperoleh ilmu dan standar kelulusan seperti pelajar sekolah pada sekolah umum.

Bidang luasan tanah diartikan bagian dari permukaan bumi yang merupakan bidang terbatas. Luasan tanah di permukaan bumi merupakan bagian dari bidang atau luasan yang terbatas keberadaannya. Oleh karena itu harus digunakan secara efektif dan efisien. Melakukan pemetaan bidang luasan tanah yaitu dengan dilakukan pengukuran posisi titik batas pada luasan tanah sehingga didapat kepastian letak bidang luasan tanah dimaksud pada permukaan bumi [2].

Data pengukuran dan gambar letak batas atas suatu luasan tanah yang diinventarisir dilapangan tersebut disimpan dikantor pertanahan selama tanah tersebut masih ada dan masih menjadi hak miliknya, sehingga dapat digunakan sebagai bahan rekonstruksi letak batas bidang tanah bila hilang sewaktu-waktu terjadi. Setiap pemilik tanah dan yang berbatasan harus dapat hadir melihat dan mengklarifikasi pengukuran serta menanda tangani hasil gambar ukur dengan surat pernyataan bahwa tanda batas pada saat pengukuran atau penetapan batas luasan tidak mengalami perubahan sebagaimana surat pernyataan kontradiktur sebelumnya [3].

Pimpinan Cabang Muhammadiyah (PCM) Gondanglegi, Kabupaten Malang mengelola Pondok Pesantren Entrepreneur Muhammadiyah (PPEM) yang merupakan salah satu unit amal usaha yang dikelola. Lahan yang digunakan oleh pondok merupakan lahan wakaf bersertifikat, dimana pemberdayaannya bertujuan memproduktifkan dan mengembangkan tanah wakaf untuk upaya mendapatkan manfaat dan hasil yang secara umum dan ketentuan ini sesuai dengan yang disyaratkan dalam Wakif [4]. 
Konsep wakaf yang seharusnya kekal, kedepan dimungkinkan mengalami perubahan oleh penguasa yang dikhawatirkan akan berubah menjadi ketidak kekalan wakaf dengan cara "res nullius", yaitu wakaf yang tak bertuan. Dalam pembahasan lingkup wakaf (waqf), seharusnya tidak ada istilah wakaf yang tak bertuan (res nullius waqf) karena semestinya wakaf merupakan kepemilikan bersama oleh seluruh umat Islam karena dihasilkan dari milik individu yang dikekalkan objeknya, dihibahkan, tidak boleh dijual dan diwariskan untuk diambil kebermanfaatannya bagi umat sesuai tujuan wakaf [5].

Seiring waktu berjalan banyak perubahan fungsi lahan yang terjadi di Gondanglegi, tidak terlepas disekitar PPEM tersebut. Alih fungsi lahan yang terjadi disekitar pondok adalah dengan adanya pembangunan perumahan ataupun kawasan terbangun lain kedepan disamping lahan pondok, batas lahan menjadi satu masalah baru, tentunya antara pengurus pondok dalam hal ini penanggung jawab, dengan pihak lain yang berkepentingan. Target dan luaran dari kegiatan pengabdian ini yaitu membantu pengurus PPEM untuk dapat menginventarisir lahan melalui pemetaan fisik. Untuk menghindari adanya perbedaan luasa faktual dan luas tanah di sertifikat nantinya [6]. Selain itu kegiatan pemetaan fisik ini juga bisa menjadi media pembelajran lapangan kepada mahasiswa yang terlibat, hal utama yang akan menjadi pembelajaran baru terhadap mahasiswa adalah penggunaan alat pengukuran Total Station, dimana selama ini mereka sudah mempelajari penggunaan Theodolite sebagai media pengukuran fisik. Dimana penggunaan Theodolite dan Total Station memiliki tingkat akurasi yang berbeda sekitar 0,2 meter hingga 0,3 m [7]. Produk kegiatan pengabdian masyarakat ini, diharapkan dapat berupa hasil pemetaan lahan pondok yang telah sesuai dengan hasil pemetaan dan memperkuat sertifikat pondok kedepan.

Maket adalah bentuk tiruan atau miniatur yang mirip dari gedung, rumah, kapal, pesawat, dan benda lainnya yang memiliki ukuran lebih kecil, biasanya terbuat dari bahan kayu, styrofoam, dan karton jerami [8]. Sehingga maket biasa digunakan untuk menunjukkan benda dengan ukuran atau skala yang lebih kecil, maket memiliki 2 (dua) jenis diantaranya adalah maket struktural dan maket arsitektur. Maket juga dapat mempresentasikan bangunan dalam bentuk tiga dimensi serta fasilitas dalam berbagai bentuknya [9].

\section{METODE KEGIATAN}

Berdasarkan eksplorasi atas permasalahan yang dihadapi dalam menginventrarisir lahan dan perencanaan pengembangan fisik, maka berikut ini adalah tahapan-tahapan pelaksanaan pengabdian yang dilaksanakan:

a. Melakukan koordinasi dengan pengurus PPEM dan survey area terbangun dan area terbuka kawasan pondok, melalui pendekatan tapak terkait kondisi fisik tapak, dan lingkungan setempat.

b. Memperkenalkan teknologi pemetaan lahan menggunakan total station dan Global Positioning System (GPS) kepada pengurus PPEM, sebagai bukti konkrit batas wilayah / lahan pondok [10]. 
c. Mendampingi pemetaan lahan pondok oleh tim pengusul pengabdian, dengan menggunakan alat total station yang terintergrasi dengan GPS, berdasarkan batas dan luasan lahan di sertifikat yang dimiliki oleh pengurus PPEM.

d. Mengolah data, dengan produk berupa gambar posisi lahan sesuai dengan hasil pemetaan dengan dasar gambar dan batas sertifikat.

Kegiatan pengabdian masyarakat ini terjadi pada masa pandemi Covid-19, dalam pelaksanaannya tim Pengabdian dibantu oleh mahasiswa peserta PMM Mitra Dosen, yang beranggotakan :

1. Yaasiinta Sekar A / 2017-069.

2. Yuni Yulia R / 2017-072.

3. Bayu Bagas Aditya G / 2017-076.

4. Ilham Bukhori / 2017-097.

5. Fidatun Nadhiroh / 2017-099.

Mahasiswa peserta PMM Mitra Dosen ini bertugas untuk membantu melakukan pemetaan batasan dan luasan areal PPEM, dan melakukan kegiatan yang terkait dengan masa pandemi COVID-19 yang sedang terjadi, yaitu melakukan penempatan stiker yang berisikan protokol kesehatan pada tiap permukiman disekitar pondok dan melakukan pemasangan hand sanitizer di beberapa titik didalam pondok. Karena penggunaan hand sanitizer merupakan upaya pencegahan yang paling mudah yang dapat dilakukan tiap individu [11].

\section{KARYA UTAMA}

Dari keseluruhan tahapan kegiatan yang telah dilakukan oleh Tim Pelaksana Pengabdian dan Mitra PPEM terkait dengan persiapan, pelaksanaan serta kegiatan bersama lainnya. Maka anggota tim pengabdian mempersembahkan suatu hasil karya utama fisik yang diharapkan bisa menjadi bukti otentik hasil kegiatan, yaitu berupa maket hasil analisa pengukuran fisik.
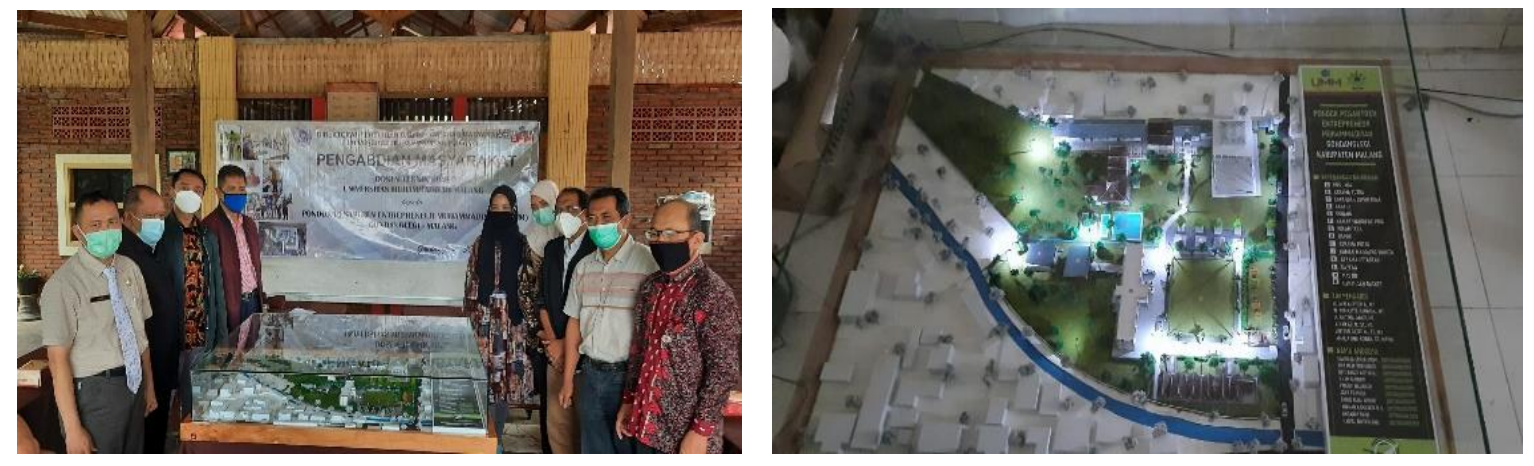

Gambar 1. Karya utama dari hasil pengukuran tim pengabdian 


\section{ULASAN KARYA}

Produk kegiatan pengabdian masyarakat ini, berupa hasil pemetaan lahan, dan maket topografi lahan pondok yang telah sesuai dengan hasil pemetaan dan membantu memperkuat proses sertifikasi pondok di BPN/TR Kabupaten Malang. Dengan beberapa dokumentasi berikut, sebagai bukti tahapan proses kegiatan yang telah dilakukan bersama Tim Pegabdian bersama mitra PPEM dilokasi pengabdian.

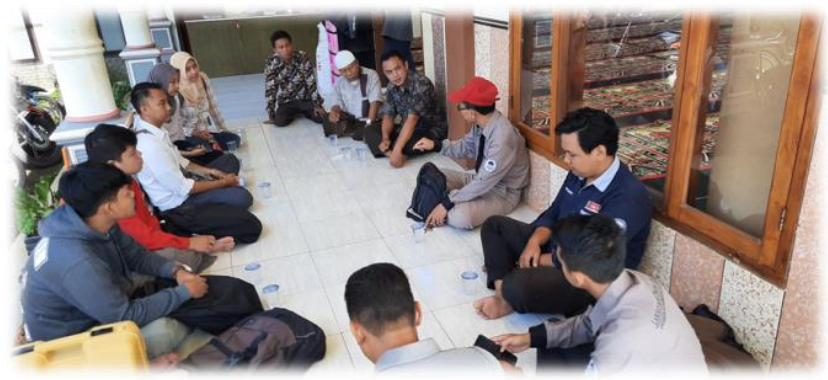

Gambar 2. Pengurus PPEM dan tim pengabdian melakukan koordinasi

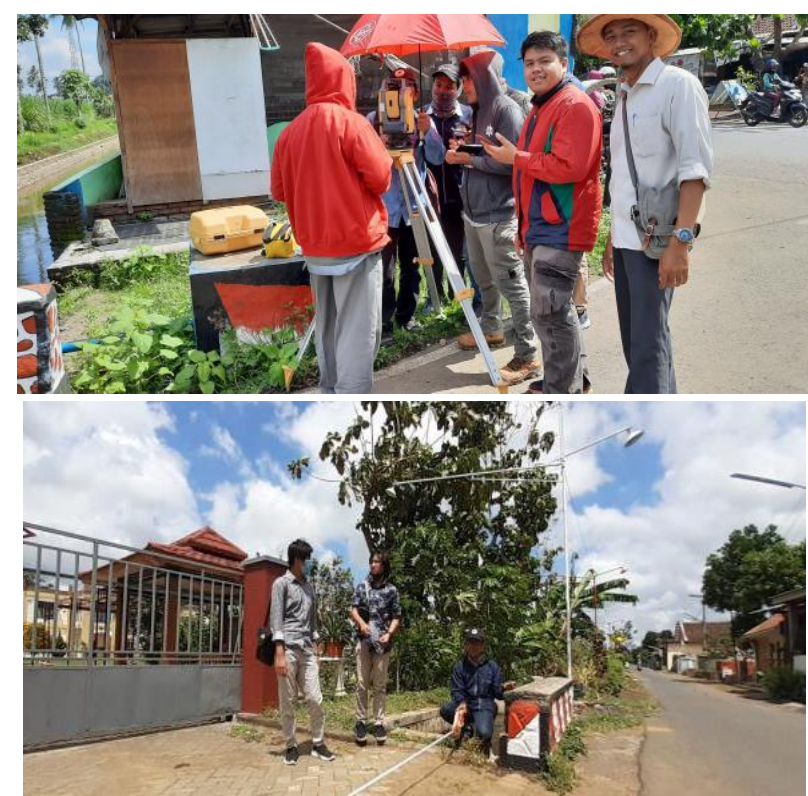

Gambar 3. Pemetaan lahan dan batas wilayah pondok menggunakan alat total station yang terintegrasi dengan GPS

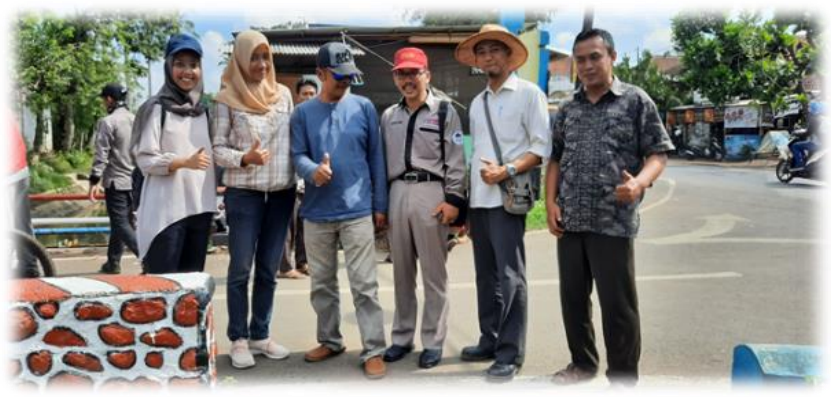

Gambar 4. Pendampingan kegiatan pemetaan lahan dan batas wilayah pondok oleh tim PPKM dan pengurus PPEM 


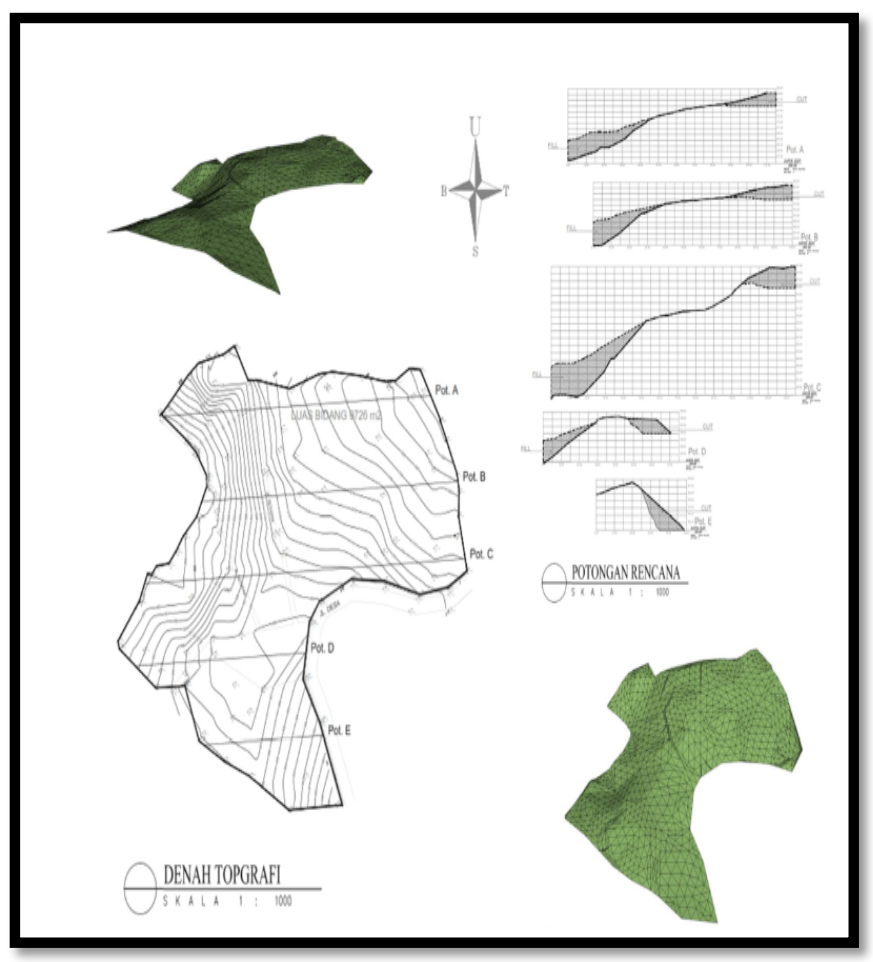

Gambar 5. Denah satu dimensi hasil analisa pengukuran topografi
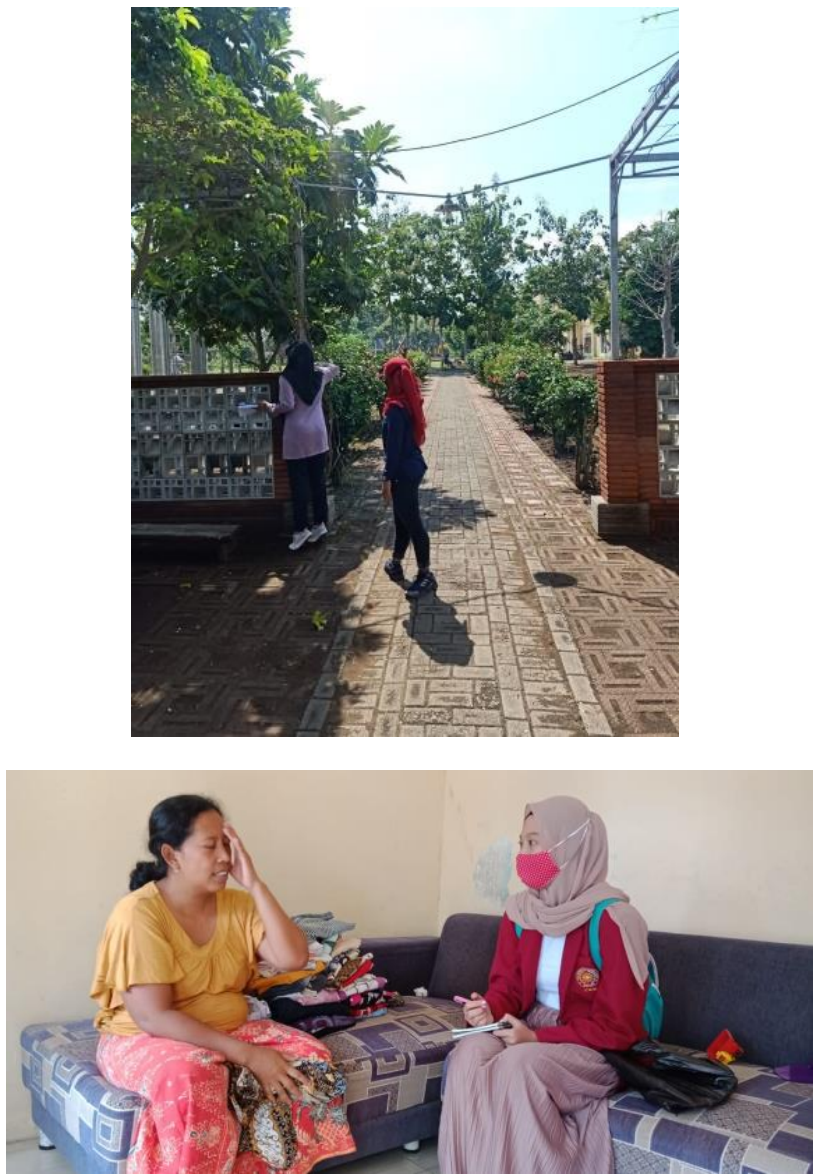

Gambar 6. Pemasangan hand sanitizer dan penempatan stiker pada tiap permukiman 

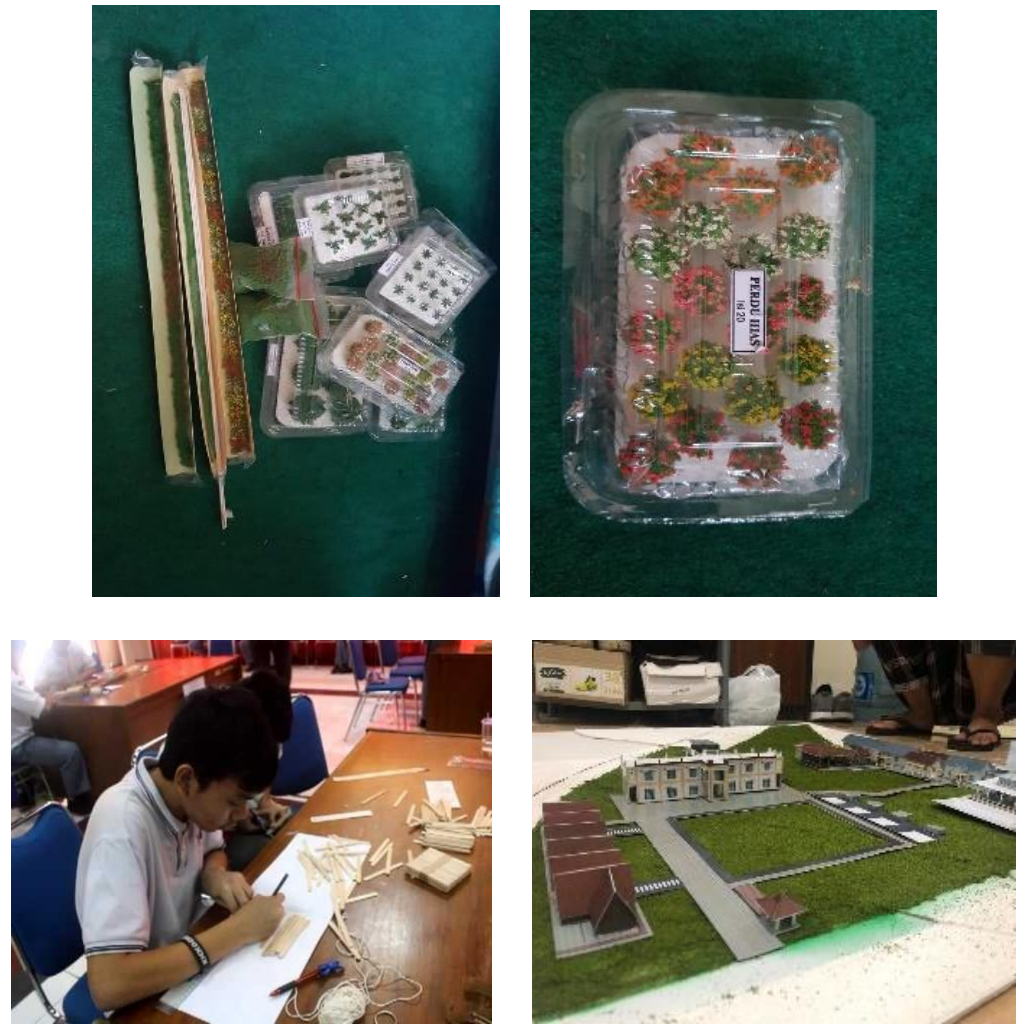

Gambar 7. Bahan dan proses pembuatan maket tiga dimensi
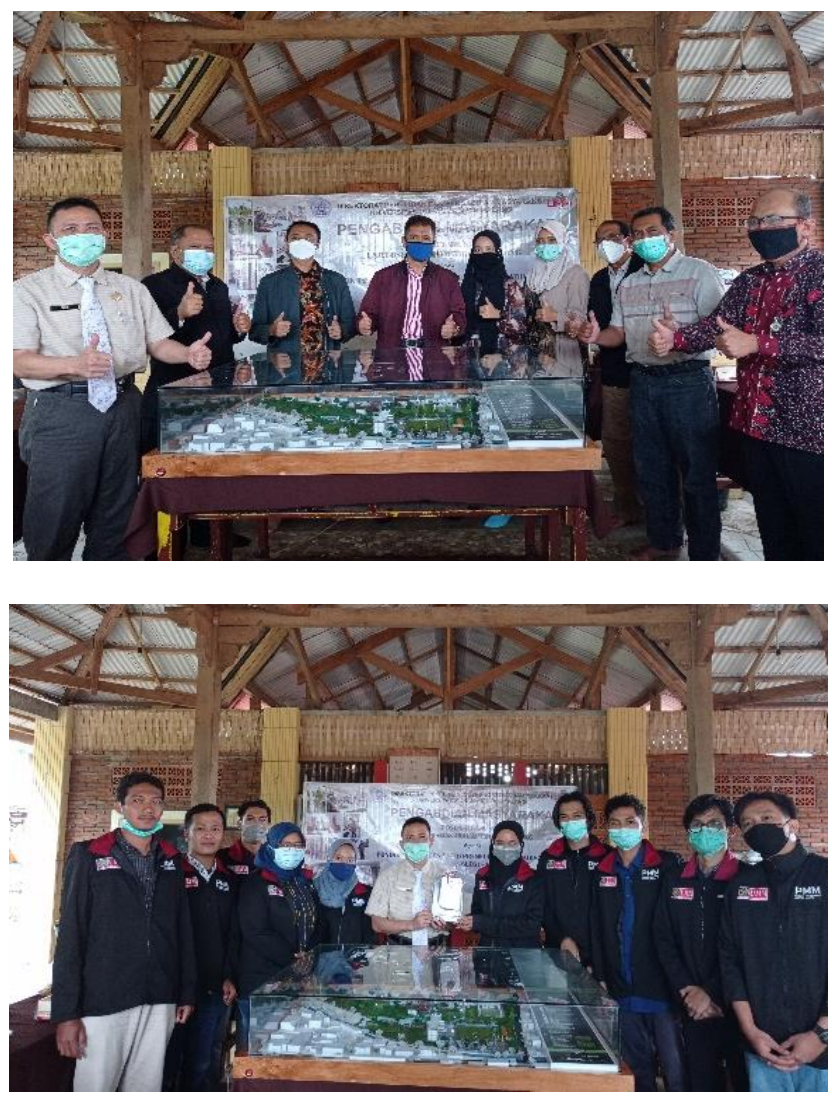

Gambar 8. Penyerahan maket dari tim pengabdi dan mahasiswa kepada mitra PPEM 


\section{DAMPAK DAN MANFAAT KEGIATAN}

Dampak dan manfaat dari program pengabdian ini yaitu :

a. Pengurus PPEM dapat menginventarisir lahan, sesuai dengan batas dan luasan di sertifikat, yang dibuktikan melalui pemetaan fisik.

b. Pengurus PPEM memiliki maket topografi lahan sesuai hasil pemetaaan.

\section{KESIMPULAN}

Kegiatan pengabdian ini dilakukan untuk membantu pihak Pondok Pesantren Entrepreneur Muhammadiyah (PPEM) dalam menginventarisir lahan, sesuai dengan batas dan luasan di sertifikat yang dapat dibuktikan melalui pemetaan fisik, memiliki maket topografi lahan sesuai dengan hasil pemetaan. Berdasarkan hasil pemetaan lahan pondok, selanjutnya dapat dilakukan pemetaan untuk bagian bangunan terbangun yang sudah ada. Hal ini juga dapat membantu mempermudah pihak pondok dalam merencanakan pembangunan bangunan pondok kedepan.

\section{PENGHARGAAN}

Ucapan terima kasih disampaikan kepada 1). Rektor Universitas Muhammadiyah Malang atas izin, pembinaannya, dan motivasinya sehingga kegiatan Tri Dharma Perguruan Tinggi ini terlaksana dengan baik. 2). Kepala Direktorat Penelitian dan Pengabdian kepada Masyarakat (DPPM) Universitas Muhammadiyah Malang atas dukungan dan arahannya melakukan kegiatan Pengabdian Kelompok ini dengan baik. 3). Mitra pengabdian atas partisipasi dan kerja samanya. 4). Seluruh anggota tim pelaksana kegiatan pengabdian dan mahasiswa yang terlibat, atas kerja samanya yang baik. Semoga apa yang telah dilakukan oleh semua pihak dalam mensukseskan kegiatan pengabdian ini dapat memberi manfaat yang sebesar-besarnya bagi masyarakat pada umumnya dan pihak pengelola PPEM pada khususnya.

\section{DAFTAR PUSTAKA}

[1] F. Amir, M. Ardi, B. A. Rauf, A. Arfandi, and A. Sa, "Penerapan Teknologi Sanitasi Lingkungan Pada Kelompok Masyarakat Berpenghasilan Rendah Di Kelurahan Ma'rang Kabupaten Pangkep,” no. 1, pp. 195-199.

[2] E. Endang, D. Apriyanti, B. Purnawan, R. R. Atmawijaya, and Y. H. M. Akbar, "Kajian Perbandingan Luas Hasil Pengukuran Bidang Tanah Dengan Metode RTK Dan Metode Polar Menggunakan ETS," Semin. Nas. Geomatika, vol. 3, p. 75, 2019, doi: 10.24895/sng.2018.3-0.920.

[3] K. Darussalam and B. Aceh, "Tatacara Penetapan Batas Tanah Dikalangan Masyarakat Kecamatan Bakongan Timur Ditinjau Menurut Konsep Mal 'Uqar,' J. Kaji. Ilmu Huk. dan Syariah, vol. 3, no. 2, 2018.

[4] Murtadho Ridwan, "Al-ijarah al-mutanaqisa: Akad alternative untuk pemberdayaan tanah wakaf," J. Ekon. Syariah, vol. 3, no. 1, pp. 140-156, 2015. 
[5] Iza Hanifuddin, "Dinamika Relasi Penguasaan Wilayah oleh Negara dan Pemilikan Aset Tanah Wakaf oleh Umat serta Ide Prospektif Penguatan Fungsi dan Daya Guna Wakaf," J. Chem. Inf. Model., vol. 53, no. 9, pp. 1689-1699, 2013, doi: http://dx.doi.org/10.21154/kodifikasia.v12i1.1425.

[6] I. Ayu, F. Anasia, and D. Suwardi, "Tanggung Gugat Perbedaan Luas Tanah Secara Faktual Dengan Luas Tanah di Sertifikat," vol. 21, no. 2, 2018.

[7] T. Sulistyo, K. Achmad, and R. B. Giarto, "Accuracy And Precision Of Determination Horizontal Distances In Stakeout Measurement Using Theodolite," vol. IV, no. II, pp. 74-77, 2019.

[8] G. A. Hidayat, "Pemanfaatan Media Maket Lansekap Berkontur Untuk Kesiapsiagaan Masyarakat Dalam Menghadapi Bencana Tanah Longsor," Univ Negeri Semarang, 2015.

[9] R. Rahmat and R. Abdullah, "Efektivitas Media Maket 3 Dimensi Karakteristik Tanah Kota Padang pada Matakuliah Mitigasi Bencana," J. Imiah Pendidik. dan ..., vol. 3, pp. 256-262, 2019, [Online]. Available: https://ejournal.undiksha.ac.id/index.php/JIPP/article/view/21833.

[10] E. Ihda, B. Sudarsono, and M. Awaluddin, "Analisis Pengukuran Bidang Tanah Dengan Menggunakan Gps Pemetaan,” J. Geod. Undip J. Geod. Undip, vol. 4, pp. 86-94, 2015.

[11] WHO, "Coronavirus disease (COVID-19) advice for the public," 2020. https://www.who.int/emergencies/diseases/novel-coronavirus-2019/advice-forpublic (accessed Dec. 07, 2020). 